J. Lake Sci. (湖泊科学), 2013, 25(4): 489-496

http: //www.jlakes.org. E-mail : jlakes@niglas.ac.cn

(C) 2013 by Journal of Lake Sciences

\title{
乌梁素海沉积物腐殖质的组成及分布特征
}

\author{
付绪金, 贾克力**, 史小红, 赵胜男, 崔风丽, 㚞才睿, 高宏斌
}

(内蒙古农业大学水利与土木建筑工程学院, 呼和浩特 010018)

\begin{abstract}
摘 要: 以乌梁素海为研究对象, 应用化学方法对乌梁素海湖泊表层沉积物有机质含量、腐殖质组成、影响腐殖质的环境 因子及腐殖化程度进行了研究,结果表明: 乌梁素海表层沉积物有机质含量变化范围为 $1.06 \%$ 5. 38\%. 有机质分布特征 与表层沉积物所处的水力条件、水生植物分布、人为活动有关; 腐殖质组成中, 胡敏酸含量为 $0.65 \sim 2.78 \mathrm{~g} / \mathrm{kg}$, 富里酸含 量为 $2.19 \sim 8.72 \mathrm{~g} / \mathrm{kg}$, 胡敏素是主体, 含量在 $3.28 \sim 20.92 \mathrm{~g} / \mathrm{kg}$ 之间; 腐殖质与环境因子的相关性分析中, 各组分含量与 有机质含量呈极显著相关. $\mathrm{pH}$ 值与胡敏素含量呈显著负相关. 溶解氧与富里酸、胡敏素含量分别呈极显著正相关、显著正 相关. 腐殖化程度分析中, 随着有机质含量的上升, 可提取腐殖质的相对含量下降. $P Q$ 值介于 $9.50 \%$ 2 $27.06 \%$ 之间, 平均 值为 $21.47 \%$,变异较大,且腐殖化程度较低.
\end{abstract}

关键词: 乌梁素海;沉积物;有机质;腐殖质;腐殖化

\section{The humus composition and distribution of Lake Wuliangsuhai sediment}

\author{
FU Xujin, JIA Keli, SHI Xiaohong, ZHAO Shengnan, CUI Fengli, FAN Cairui \& GAO Hongbin
}

( College of Water Conservancy and Civil Engineering of Inner Mongolia Agricultural University, Huhhot 010018, P. R. China)

\begin{abstract}
The paper studied the organic matter contents, humus composition and the degree of humification of the surface sediment of Lake Wuliangsuhai by chemical method. Correlation between sediment humus and physical-chemical factors were also discussed. The results showed that the organic matter of the surface sediment varied from $1.06 \%$ to $5.38 \%$. Their distribution characteristics were related to hydraulic condition, aquatic plant distribution and human activities. In the humus composition, the content of humic acid and fulvic acid varied from 0.65 to $2.78 \mathrm{~g} / \mathrm{kg}$ and from 2.19 to $8.72 \mathrm{~g} / \mathrm{kg}$, respectively. The humin is the main component in the sediment, ranging from 3.28 to $20.92 \mathrm{~g} / \mathrm{kg}$. Based on the correlation analysis of humus and environmental factors, each component is significantly correlated with the organic matter content. The $\mathrm{pH}$ value is significantly negative correlated with humin. Dissolved oxygen is significantly positive correlated with fulvic acids and significantly positive correlated with humin. The organic matter content increased while the content of extracted humic substances is decreased in the humification analysis. The $P Q$ values range from $9.50 \%$ to $27.06 \%$, with the average of $21.47 \%$, which varied dramatically and with low degree of humification.
\end{abstract}

Keywords: Lake Wuliangsuhai; sediment; organic matter; humus; humification

湖泊沉积物可以分为化学沉积、生物沉积和碎屑沉积 3 种类型, 来自于水体内部和水体外部 2 种途 径. 沉积物作为湖体中一切沉降物的载体, 不断接纳来自流域内随水体人湖的大部分无机和有机颗粒物、 湖体内水生生物的死亡残体和排泄物, 以及水体内化学与生物化学作用的沉淀物等 ${ }^{[1]}$. 所以湖泊沉积物 被视为湖泊环境的重要信息库,既能成为水体污染的汇, 又可能成为水体污染的源 ${ }^{[2-3]}$. 由于有机质的普 遍存在,使其具有重要的生态和环境意义,作为全球碳循环的重要组成部分,它对全球变化有重要影响, 也是生态系统中能量与物质循环的重要途径, 更是各种养分 (碳、氮、磷和硅) 循环的关键环节 ${ }^{[4]}$. 由于有 机质矿化过程大量耗氧, 同时释放出 $\mathrm{C} 、 \mathrm{~N} 、 \mathrm{P} 、 \mathrm{~S}$ 等营养盐, 可以造成严重的水质恶化、水体富营养化 ${ }^{[5]}$. 此

* 内蒙古自治区重大科技项目 (20091408) 资助. 2012-11-12 收稿;2012-12-25 收修改稿. 付绪金, 男, 1986 年生, 硕士研究生; E-mail : fuxujin2010@163.com.

** 通信作者;E-mail:kelijia58@yahoo. com.cn. 
外, 还有可能造成湖泊萎缩、生物多样性下降等一系列威胁湖泊生态安全的问题, 进而严重影响湖泊在城 乡饮用供水、工农业用水、渔业养殖及其旅游业等方面的重要作用. 有机质在湖泊环境中扮演着重要角 色, 国内外许多学者一直致力于有机质对于湖泊环境的研究 ${ }^{[6-12]}$. 近年来, 关于湖泊有机质的研究集中于 湖泊水体与沉积物等方面,包括其分布特征、影响因素、污染评估、组成成分等 ${ }^{[13-17]}$. 有机质的化学组成、 结构和来源是研究其影响湖泊环境的基础, 紫外一可见光谱、苂光光谱、高效体积排阻色谱和沉积物中的 微生物 DNA 分析技术等研究手段的应用, 使得有机质组分研究取得了更为深人和广泛的进展 ${ }^{[18-22]}$. 有机 质的最主要成分是腐殖质 ${ }^{[23]}$, 腐殖质广泛存在于土壤、水体及沉积物中, 是自然环境中广泛存在的一类无 定形、呈棕褐色或棕黑色、亲水性、酸性、多分散的天然有机大分子物质. 腐殖质内带有多种活性官能团, 如羟基、酚羟基、醇羟基、羧基等,具有较强的络合、螯合、吸附和强氧化能力 ${ }^{[24-27]}$, 其主要组成元素为 $\mathrm{C}$ 、 $\mathrm{H} 、 \mathrm{O} 、 \mathrm{~N}$ 和 $\mathrm{S}$. 根据在水体中溶解性的不同, 腐殖质可以分为 3 类: 胡敏酸 ( humic acids, HA, 仅溶于碱性溶 液而不溶于酸性溶液)、富里酸 (fulvic acids, FA, 既溶于碱性又溶于酸性溶液) 、胡敏素 ( humin, HM, 既不 溶于碱性也不溶于酸性溶液). 可溶解部分的 HA 和 FA 合称为可提取腐殖质 (HE). 因此, 腐殖质对湖泊 营养元素循环过程起着重要作用.

目前, 国内湖泊中有机质的研究主要集中于东部平原湖区与云贵高原湖区, 对于高寒、干旱半干旱地 区的蒙新高原湖区、东北平原与山地湖区、青藏高原湖区的湖泊有机质的污染研究涉及较少, 而这些地区 季节温差大、湖泊冰封期长、太阳辐射强、降雨稀少、蒸发强烈、干湿期差异大, 特别是秋末冬初, 受冷空气 活动影响且寒潮天气过程比较频繁. 乌梁素海位于中国北方寒旱区黄河河套平原末端, 属于蒙新高原湖 区的草型湖泊, 是当地农田退水、工业废水和生活污水的唯一承泄渠道. 由于农田退水、工业废水、生活污 水携带大量营养盐、有机质等排人乌梁素海, 使其富营养化严重, 湖泊内水生植物逐年递增, 水生植物的 死亡以及外源有机污染物的输人造成湖底高程逐年增高, 沉积物中的有机质含量发生变化, 水环境发生 恶性循环 ${ }^{[28-31]}$. 因此在这种气候和上游污染物排放特性的影响下, 乌梁素海有机质和腐殖质的组成、 分布特征等必定有其特殊性. 此外, 乌梁素海是全球同纬度最大的湿地, 不仅对维持湖泊流域地区生 态系统平衡起着重要作用, 并且集河套灌区排水、渔业生产、芦苇养殖和旅游等多个社会功能于一体, 具有较大的生态意义. 但是关于乌梁素海沉积物有机质组分的研究尚不深人, 因此, 本文以乌梁素海 为研究对象, 对其沉积物有机质含量、组成和影响因子进行深人分析, 不仅可为干旱半干旱地区湖泊 污染治理和科学管理体系的建立提供基础资料, 也为湖泊生态安全、合理利用湖泊自然资源等方面的 技术研究提供科学依据.

\section{1 材料与方法}

\section{1 研究区域概况}

乌梁素海位于我国北方的内蒙古自治区巴彦淖尔市乌拉特前旗境内, 是黄河改道后形成的牛轭湖, 是 全球范围内荒漠半荒漠地区极为少见的具有生物多样性和环境保护等多功能的大型草型湖泊. 乌梁素海 $\left(40^{\circ} 36^{\prime} \sim 41^{\circ} 03^{\prime} \mathrm{N}, 108^{\circ} 43^{\prime} \sim 108^{\circ} 57^{\prime} \mathrm{E}\right)$ 是全球同纬度地区内最大的湖泊, 现有水域面积 $285.38 \mathrm{~km}^{2}$, 芦苇 区面积 $118.97 \mathrm{~km}^{2}$, 明水区面积 $111.13 \mathrm{~km}^{2}$. 明水区中 $85.7 \mathrm{~km}^{2}$ 为沉水植物密集区, 其余为沼泽区. 湖水于 每年 11 月初结冰, 直到翌年 3 月末到 4 月初开始融化, 冰封期约为 5 个月 ${ }^{[32]}$. 乌梁素海是河套灌区排灌水 系的重要组成部分, 是当地农田退水、工业废水和生活污水的唯一承泄渠道. 由于河套灌区化肥和农药的用 量不断加大, 而且化肥利用率较低, 上游的工业废水和生活污水随着农田退水进人乌梁素海, 使得大量营养 盐沉积, 腐烂的水草和挺水植物、各种浮游生物残骸以每年 $10 \mathrm{~mm}$ 左右的速度沉积至湖底, 形成内源污染, 也加快了乌梁素海的沼泽化进程 ${ }^{[33]}$.

\section{2 样品采集}

根据《湖泊生态系统观测方法》 ${ }^{[34]}$, 于 2012 年 2 月 14 日进行了样品采集. 根据乌梁素海地形地貌及湖 面冰冻特点, 设置 11 个采样点 (图 1). 由于采样时间处于冬季冰封期, 湖区南部冰冻层较薄, 无法进行采样. 
冰冻湖面破冰钻孔后, 利用自行研制的柱状采泥器采 集表层柱状样品 $10 \mathrm{~cm}$, 装人聚乙烯塑封袋封口冷藏保 存. 样品带回实验室, 新鲜样品置于 $4^{\circ} \mathrm{C}$ 冰箱中保存; 自 然条件下风干, 剔除动植物残体, 过篮装袋得到风干样 品备用.

\section{3 分析方法}

有机质总量采用重铬酸钾氧化外加热法测定 ${ }^{[35]}$, 腐殖质采用 $0.1 \mathrm{~mol} / \mathrm{L}$ 焦磷酸钠和 $0.1 \mathrm{~mol} / \mathrm{L}$ 氢氧化 钠混合液提取法测定 ${ }^{[36-37]}, \mathrm{pH}$ 采用土液比 $1: 2.5$ 进 行测定 $^{[38]}$. 实验数据分析及图形绘制分别采用 SPSS 和 ArcGIS 软件.

\section{2 结果与分析}

\section{1 沉积物腐殖质的含量及分布特征}

乌梁素海表层沉积物有机质水平分布呈现出一定 的区域特点, 总体含量在 $1.06 \% \sim 5.38 \%$ 之间, 平均值 为 $3.23 \%$ (图 2a). 乌梁素海总排干人湖口处的 J11 点 有机质含量比较低, 为 $1.57 \%$, 低于湖区平均水平, 这 主要是因为河口处水力条件比较强烈, 水流速度较快, 不能为动植物及微生物残体尤其是芦苇根部的沉积提 供好的动力条件. 与 $\mathrm{J} 11$ 点处于同一纬度的 $\mathrm{J} 13$ 点有机 质含量最低,为 $1.06 \%$, 这主要是因为该点处于开阔水 域, 同时沉水植物较少, 表层沉积物来源较少. 湖泊东 部的 M14 点及 P11 点有机质含量较低,有机质含量分

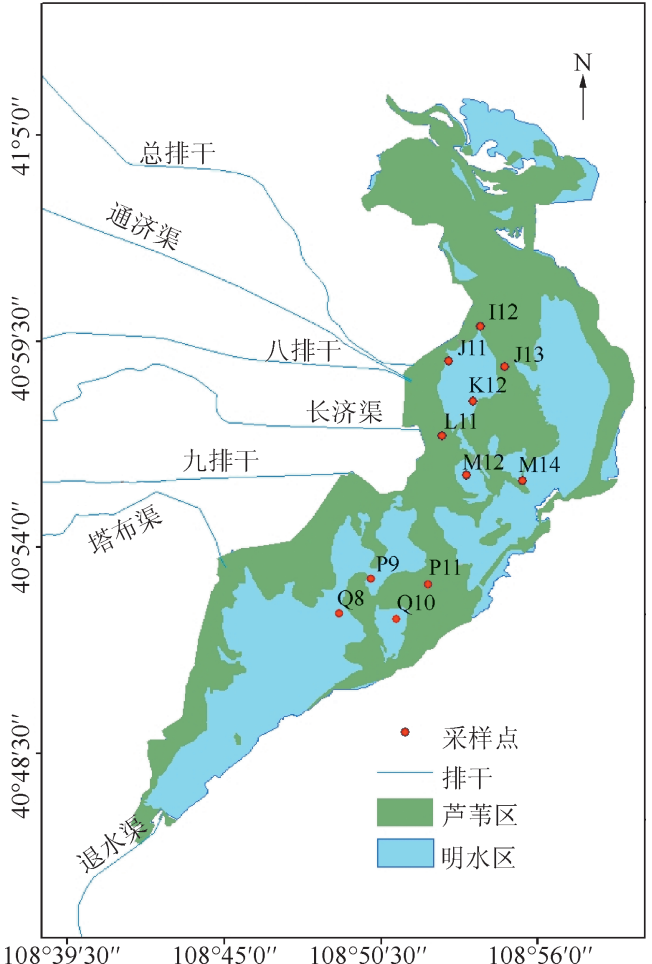

图 1 乌梁素海采样点分布

Fig. 1 Location of sampling sites of Lake Wuliangsuhai 别为 $2.35 \%$ 和 $1.97 \%$,主要由于这 2 点均处于旅游区 附近, 人为干扰比较强烈. 有机质的分解转化过程包括矿化和腐殖化过程,关于昆明湖的沉积物有机质特征 的研究发现, 旅游活动强大的水域水体沉积物有机质矿化作用明显较强 ${ }^{[39]}$. 同样, 乌梁素海旅游区的有机质 含量较低,很可能也是矿化作用的结果. 有机质含量较高的点有湖区中部芦苇密集区的 L11、M12 点和湖区 南部的沉水植物密集区 Q8 点,有机质含量分别为 5.38\%、4.50\% 和 4.56\%.总体来讲,乌梁素海表层沉积 物有机质水平分布特征为湖区西部高于东部. 表层沉积物中有机质主要来源于湖中大面积分布的、以芦苇 为主的挺水植物和以龙须眼子菜为优势种的湖底沉水植物, 乌梁素海水体富营养化具有明显的内源性,这 与相关研究结论一致 ${ }^{[40-41]}$.

各组分含量及占有机质的百分比表明 (表 1), HA 的含量范围为 $0.65 \sim 2.78 \mathrm{~g} / \mathrm{kg}$, 平均值为 $1.37 \mathrm{~g} / \mathrm{kg}$; $\mathrm{FA}$ 的含量范围为 $2.19 \sim 8.72 \mathrm{~g} / \mathrm{kg}$, 平均值为 $5.08 \mathrm{~g} / \mathrm{kg}$; HM 的含量范围为 $3.28 \sim 20.92 \mathrm{~g} / \mathrm{kg}$, 平均值为 $12.29 \mathrm{~g} / \mathrm{kg}$. 从水平分布上看 $\mathrm{HE} 、 \mathrm{HA} 、 \mathrm{FA} 、 \mathrm{HM}$ 分布特点均与有机质分布特点相似,东部开阔水域含量较低, 西部芦苇密集区及湖区南部含量较高 (图 2), 这说明提取的 HA、FA、HM 与直接提取的有机质分布具有 一致性.

乌梁素海表层沉积物腐殖质中不溶性的 HM 占主导地位, HM 是腐殖质中与土壤矿物质结合最紧密的 组分, 酸碱及有机溶剂等均无法提取, 是一种情性腐殖质, 可以在土壤中存在上千年, HM 失去溶解性的根本 原因是它和铁铝化合物及黏粒矿物等无机组分牢固结合 ${ }^{[42]}$. 乌梁素海表层沉积物腐殖质可溶解部分的 FA 平均含量高于 $\mathrm{HA}, \mathrm{FA}$ 和 $\mathrm{HA}$ 的形成顺序及相互转化主要是由环境条件的不同造成的 ${ }^{[43]}$. 整体而言,乌梁素 海表层沉积物腐殖质各组分的平均含量大小为: $\mathrm{HM}>\mathrm{FA}>\mathrm{HA}$ (表 1$)$. 

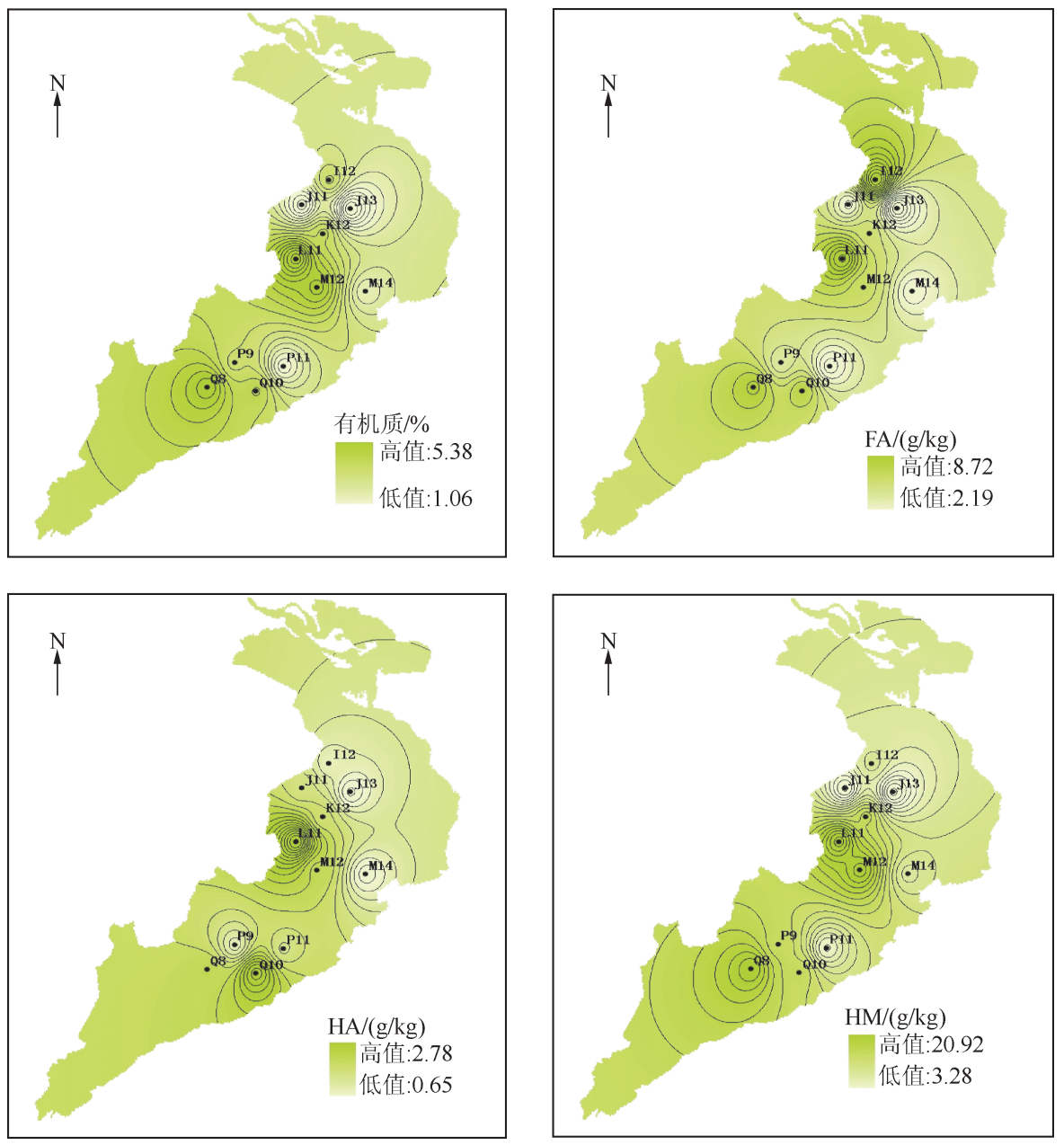

图 2 乌梁素海表层沉积物有机质、FA、HA、HM 分布特征

Fig. 2 The distribution characteristics of organic matter, FA, HA and HM of the surface sediment of Lake Wuliangsuhai

表 1 乌梁素海表层沉积物有机质 $(\mathrm{OM})$ 及组分分析

Tab. 1 Composition and total content of OM of the surface sediment of Lake Wuliangsuhai

\begin{tabular}{cccccccc}
\hline \multirow{2}{*}{ 采样点 } & \multicolumn{7}{c}{ 各组分含量及其所占有机质百分比 } \\
\cline { 2 - 7 } & $\mathrm{HE} /(\mathrm{g} / \mathrm{kg})$ & $\mathrm{HA} /(\mathrm{g} / \mathrm{kg})$ & $\mathrm{HA} / \mathrm{OM} / \%$ & $\mathrm{FA} /(\mathrm{g} / \mathrm{kg})$ & $\mathrm{FA} / \mathrm{OM} / \%$ & $\mathrm{HM} /(\mathrm{g} / \mathrm{kg})$ & $\mathrm{HM} / \mathrm{OM} / \%$ \\
\hline $\mathrm{I} 12$ & 9.63 & 0.91 & 2.69 & 8.72 & 25.62 & 10.10 & 29.70 \\
$\mathrm{~J} 11$ & 4.88 & 1.25 & 7.96 & 3.62 & 23.02 & 4.25 & 27.02 \\
$\mathrm{~J} 13$ & 2.84 & 0.65 & 6.12 & 2.19 & 20.79 & 3.28 & 31.10 \\
$\mathrm{~K} 12$ & 6.46 & 1.35 & 3.73 & 5.11 & 14.08 & 14.59 & 40.20 \\
$\mathrm{~L} 11$ & 10.31 & 2.78 & 5.16 & 7.53 & 13.99 & 20.92 & 38.86 \\
M12 & 6.92 & 1.52 & 3.38 & 5.39 & 11.98 & 19.19 & 42.64 \\
M14 & 4.20 & 0.72 & 3.05 & 3.48 & 14.81 & 9.44 & 40.15 \\
P9 & 5.33 & 0.94 & 2.86 & 4.39 & 13.32 & 13.78 & 41.82 \\
P11 & 4.43 & 1.20 & 6.09 & 3.23 & 16.42 & 6.98 & 35.50 \\
Q8 & 7.82 & 1.54 & 3.37 & 6.28 & 13.79 & 18.61 & 40.84 \\
Q10 & 8.05 & 2.16 & 5.68 & 5.89 & 15.48 & 14.01 & 36.84 \\
\hline
\end{tabular}




\section{2 腐殖质与环境因素的相关性}

湖泊沉积物腐殖质的含量与分布差异, 主要受湖泊外部的环境条件如温度、湿度以及湖泊水环境的内 部条件如酸碱性、氧化还原性等各种因素共同影响. 研究沉积物腐殖质组成对湖泊水环境的影响机制, 必须 从探讨其影响因素出发,找出影响因子对其进行调控. 本研究利用数据分析工具,结合野外定期采样的实验 数据与基础理论,对腐殖质与环境因子间的关系进行综合研究.

有机质含量与 $\mathrm{HA} 、 \mathrm{FA} 、 \mathrm{HM}$ 均呈显著正相 关,相关系数达到 $0.5425 、 0.6118$ 和 0.9566 (图 3a, $P<0.01$ ), 这表明腐殖质各组分含量 均随着有机质含量的增加而增加.

沉积物的酸碱性对有机质的影响主要包 括降低有机质的溶解性,改变具有可变负电荷 的土壤中有机物一矿质相互作用, 增加生物毒 性阳离子的数量, 改变微生物种群组成和数量 以及沉积物中微生物活性和酶活性. 沉积物酸 碱度的变化必然会影响沉积物有机质周转过 程 ${ }^{[44]}$. 乌梁素海表层沉积物 $\mathrm{pH}$ 在 7.6 8.2 之间, 属于中性一弱碱性环境. 乌梁素海表 层沉积物的 $\mathrm{pH}$ 值与 $\mathrm{HM}$ 呈显著负相关 $\left(R^{2}=\right.$ $0.5142, P<0.05), \mathrm{HA} 、 \mathrm{FA}$ 与表层沉积物 $\mathrm{pH}$ 值相关性不显著 (图 3b). 相关研究表明, $\mathrm{pH}$ 值主要通过影响微生物的活动, 从而影响土壤 有机质的分解与矿化, $\mathrm{pH}$ 值越高, 有机碳分解 速度越快, 有机质含量越低 ${ }^{[45]}$.

水体溶解氧反映大气溶解与植物光合作 用放氧过程和生物呼吸作用好氧过程之间的 暂时平衡. 溶解氧的变化会改变水土界面和沉 积物内部微生物的区系组成、种群组合和数 量 ${ }^{[46]}$, 进而影响沉积物中腐殖质的含量. 乌梁 素海冰封期约为 5 个月, 在冰雪覆盖下, 且冬 季光照条件较差, 水体光合作用很低, 而呼吸 作用一直在持续, 从而导致乌梁素海水体溶解 氧的降低. 在非冰封期, 光照条件充足, 光合作 用强, 水体溶解氧含量较高. 水体溶解氧与 $\mathrm{FA}$ 呈极显著正相关 $\left(R^{2}=0.9514, P<0.01\right)$; 与 $\mathrm{HM}$ 呈显著正相关 $\left(R^{2}=0.3716, P<0.05\right)$ ( 图 $3 \mathrm{c})$. 由此说明,乌梁素海水体溶解氧含量影响 着 FA、HM 的含量, 溶解氧越高, 生物氧化的进
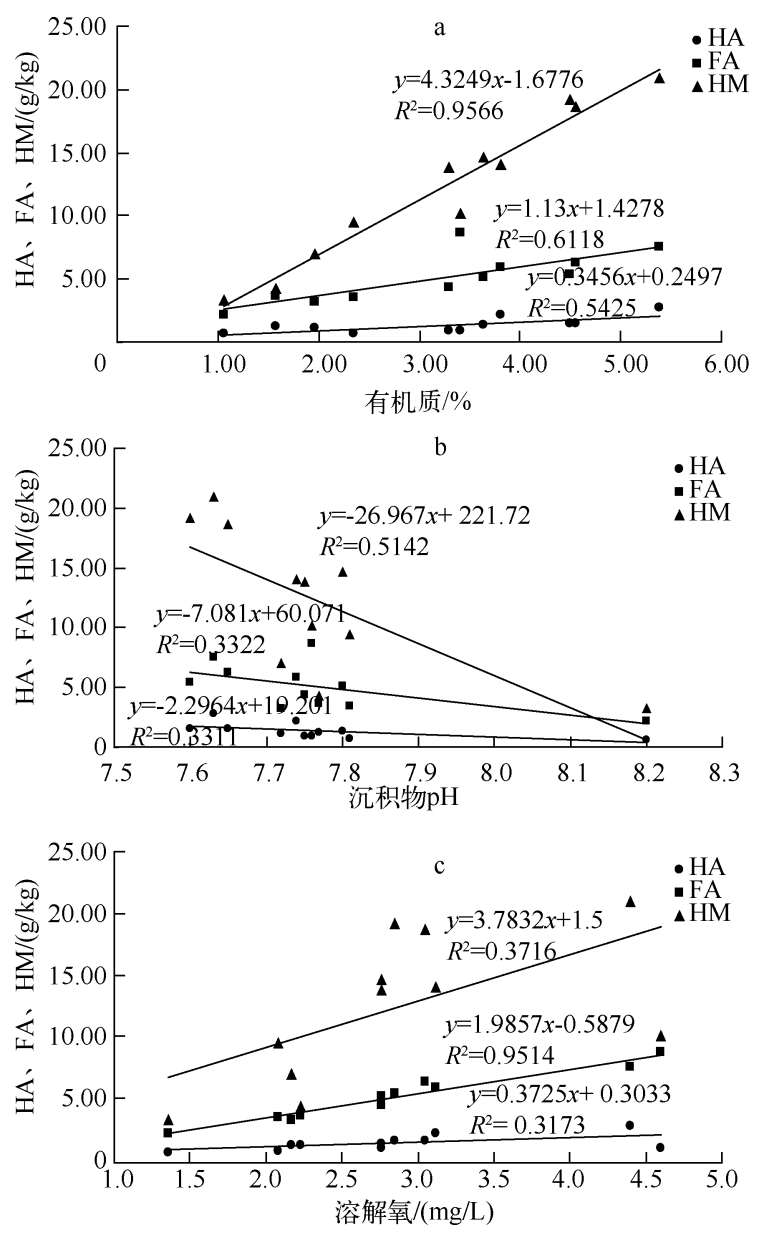

图 3 乌梁素海表层沉积物有机质 $(\mathrm{a}) 、 \mathrm{pH}(\mathrm{b})$ 和水体 溶解氧 (c) 与 HA、FA、HM 相关关系

Fig. 3 The correlation of organic matter(a), $\mathrm{pH}(\mathrm{b})$ of the surface sediment and water dissolved oxygen(c) with HA, FA, HM in Lake Wuliangsuhai 行和微生物间相互作用越强, FA、HM 的含量 越高.

\section{3 腐殖化程度分析}

腐殖化过程指在微生物的作用下, 土壤或江河湖海等水体沉积物中有机质转变成腐殖质的过程. 沉积 物腐殖化的程度是衡量腐殖质品质优劣及稳定性的标志之一 ${ }^{[47]}$, 可以用 $P Q$ 值来表示, $P Q$ 值是 $\mathrm{HA}$ 占可提 取腐殖质 $(\mathrm{HE})$ 的质量分数, 表征腐殖质组成的变化. HA 所占的比例越高, 腐殖质品质越好, 肥力越高 ${ }^{[48]}$. 乌梁素海 $P Q$ 值介于 $9.50 \%$ 27.06\% 之间, 平均值为 $21.47 \%$ (图 4). 这可能是因为乌梁素海处于温带干旱 


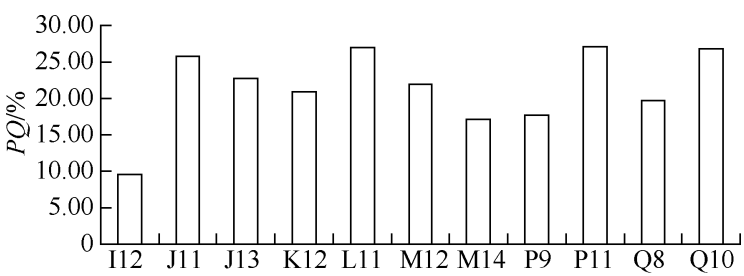

图 4 乌梁素海表层沉积物 $P Q$ 值分布特征

Fig. 4 The $P Q$ value distribution characteristics of the surface sediments of Lake Wuliangsuhai
半干旱地区, 采样时间处于冬季, 气温较低, 降 雨量较小, 不利于发生腐殖质缩合反应, 导致 其腐殖化程度较低; 也可能是因为腐殖质在微 生物的作用下发生矿化作用, 有机碳及营养物 质再次被分解为简单的无机物, 具体原因尚需 进一步研究. 不同采样点表层沉积物 $P Q$ 值变 化较大, 表明表层沉积物腐殖化程度存在空间 差异, 芦苇和沉水植物密集区腐殖化程度比较 严重, 从一定程度上反映了腐殖化进程与水生 植物的关系.

$\mathrm{HE}$ 的相对含量即为可提取腐殖质占沉积物总有机质的百分比. HE 与有机质的比值 (HE/OM) 表示腐 殖化进程中的有机碳的活性. HE 组成复杂, 存在各种各样官能团, 能够影响和控制水体中重金属和持久性 有机污染物的迁移转化, 进而影响其毒性和生物可得性 ${ }^{[24]}$. 随着表层沉积物有机质含量的不断上升, HE 的 相对含量呈逐渐下降趋势, 且两者呈负相关 $\left(R^{2}=0.3891, P<0.05\right.$ ) (图 5, 图 6a). HE 的绝对含量与有机质 含量呈正相关 $\left(R^{2}=0.7196, P<0.01\right.$ ) (图 6b). 这种情况可能说明, $\mathrm{HE}$ 与有机质含量同时增加, 但是 $\mathrm{HE}$ 增 加的幅度小于有机质增加的幅度.

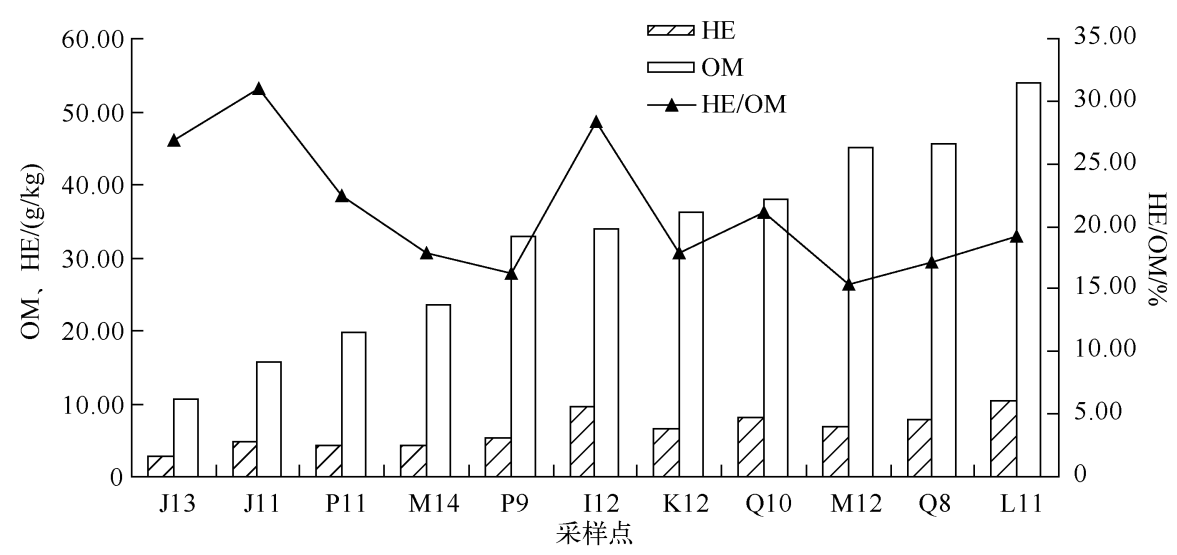

图 5 乌梁素海表层沉积物的有机质、HE、HE/OM

Fig. 5 Contents of organic matter, HE and HE/OM of the surface sediments of Lake Wuliangsuhai
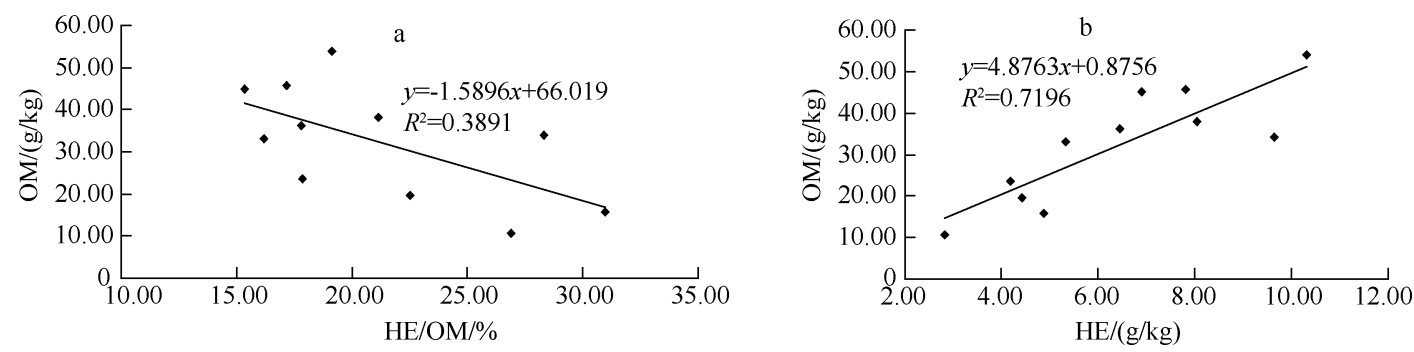

图 6 乌梁素海表层沉积物 $\mathrm{OM}$ 与 $\mathrm{HE} / \mathrm{OM}(\mathrm{a}) 、 \mathrm{HE}(\mathrm{b})$ 的相关关系

Fig. 6 The correlation of organic matter with $\operatorname{HE} / \mathrm{OM}(\mathrm{a}), \mathrm{HE}(\mathrm{b})$ of the surface sediments of Lake Wuliangsuhai

\section{3 讨论}

乌梁素海有机质含量为 $1.06 \% \sim 5.38 \%$, HA 占有机质的百分比为 $2.69 \% \sim 7.96 \%$, FA 占有机质百分比 
为 $11.98 \% \sim 25.62 \%, \mathrm{HM}$ 占有机质百分比为 $27.02 \% \sim 42.64 \%$ (表 1). 对比长江中下游洞庭湖、鄱阳湖、巢 湖、太湖、月湖和玄武湖等亚热带湖泊沉积物理化性质 ${ }^{[3]}$ 发现, 乌梁素海各项组分在有机质中的百分比及腐 殖化程度均低于长江中下游湖泊. 与同样处于干旱半干旱地区的内蒙古东部高原的碳酸盐碱湖泊达里诺尔 湖相比, 乌梁素海表层沉积物腐殖质各组分含量中 FA 的含量高于达里诺尔湖, HM 含量低于达里诺尔湖, 也 没有表现出径向分异特征 ${ }^{[49]}$.

综合分析, 湖泊沉积物腐殖质的形成以及积累是各种自然因素综合作用的结果,包括水热条件、微生物 作用、地理位置、气候条件等, 其中水热条件尤为重要. 文启孝认为腐殖质的组成变异表明排水不良或渍水 条件有利于 HA 的积累, 高温或常年低温不利于 HA 积累 ${ }^{[50]}$; 湖泊沉积物中有机质与腐殖质之间的关系十 分密切, 沉积物中有机质形成和积累同样以水热条件最为重要 ${ }^{[51]}$; 其次, 沉积物中微生物活动旺盛, 微生物 与结构复杂、性质稳定的腐殖质之间相互作用可使其全部或部分分解, 与此同时产生新的腐殖质使有机质 得到更新 ${ }^{[52]}$; 此外,金相灿等的研究还发现,我国东部的黑龙江、松花江、黄河、长江、钱塘江、闽江等 27 条河 流悬浮沉积物中有机质的含量及组成具有明显的地带性分布, 腐殖酸含量则自北而南逐渐降低 ${ }^{[53]}$; 因地理 位置改变而呈现的气候变化, 同样影响了微生物活动, 从而影响有机质的变化, 凉爽季节向温暖季节转化会 导致有机质的变化, 热、湿润气候有利于有机质的分解 ${ }^{[54]}$. 因此, 腐殖质的形成与所处的环境条件密切相关. 乌梁素海地处中国北方寒旱区,季节温差大、太阳辐射强、降雨稀少、蒸发强烈、干湿期差异大, 湖泊冰封期 长, 每年大约有 $4 \sim 6$ 个月的冰封期, 使得湖泊长期处于低温状态, 因此沉积物中腐殖质各组分含量较低, 较 其他湖泊具有一定的特殊性, 本文的研究结果也为其他高寒、干旱半干旱地区湖泊有机质污染研究提供了 一定的数据支撑与研究基础.

致谢: 审稿专家对本文的修改提出了许多宝贵建议, 谨致谢忱.

\section{4 参考文献}

[1] 范成新,张 路. 太湖:沉积物污染与修复原理. 北京:科学出版社, $2009: 2,112$.

[2] 梁 文,张 生,李畅游等.乌梁素海沉积物分布特征. 环境化学,2011,30(9):1678-1679.

[ 3 ] 易文利,王圣瑞,杨苏文等. 长江中下游浅水湖泊沉积物腐殖质组分赋存特征. 湖泊科学, 2011,23(1):21-28.

[ 4 ] 吴丰昌,王立英,黎 文等. 天然有机质及其在地表环境中的重要性. 湖泊科学,2008,20(1) :1-12.

[ 5 ] 朱广伟,陈英旭. 沉积物有机质的环境行为研究进展. 湖泊科学, 2001,13(3):272-279.

[6]秦伯强,朱广伟. 长江中下游地区湖泊水和沉积物中营养盐的赋存、循坏及其交换特征. 中国科学: D 辑: 地球科 学, 2005,35(增刊 II ) : 1-10.

[ 7 ] 何宗健,刘文斌,王圣瑞等. 洱海表层沉积物吸附磷特征. 环境科学研究,2011,24(11):1242-1248.

～8 ] 易文利. 湖泊沉积物中有机质含量对释放磷的影响. 科学技术与工程, 2011,11(26):6401-6404.

[ 9 ] 胡春华. 太湖五里湖沉降通量及其有机质分解研究. 海洋与湖沼, 2000,31(3):327-333.

[10］罗潋苟,秦伯强. 太湖波浪与湖流对沉积物再悬浮不同响应的研究. 水文, 2003,23(3):1-4.

[11] 黎 文,吴丰昌,傅平清等. 贵州红枫湖水体溶解有机质的剖面特征和季节变化. 环境科学, 2006,27 (10): 1979-1985.

[12] Wu FC, Evans RD, Dillon PJ. High-performance chromatographic fractionation and characterization of fulvic acid. Analytica Chimica Acta ,2002,464:47-55.

[13] 祝 鹏, 华祖林, 郭建阳等. 太湖溶解有机质光谱和氮磷污染的区域分布差异特征. 环境科学研究, 2010,23 (2): 129-136.

[14] 齐红艳,范德江,徐 琳. 长江口及邻近海域表层沉积物 $\mathrm{pH} 、 \mathrm{Eh}$ 分布及制约因素. 沉积学报, 2008, 26 (5):820-827.

[15] 曹 军,陶 澍. 土壤与沉积物中天然有机物释放过程的动力学研究. 环境科学学报, 1999,19(3):297-302.

[16] 赵 营, 成杰民,鲁成秀. 不同生态类型富营养化湖泊沉积物中有机质赋存形态. 环境化学, 2012,31(3):302-307.

[17] 傅平青, 吴丰昌, 刘丛强. 高原湖泊溶解有机质的三维荧光光谱特性初步研究. 海洋与湖沼, 2007, 38 (6) :512-520.

[18 ] Her N, Amy G, McKnight D et al. Characterization of DOM as a function of MW by fluorescence EEM and HPLC-SEC using UVA, DOC, and fluorescence detection. Water Research ,2003,37:4295-4303.

[19] Pwolfe A, Kaushal S, Fulton J. Spectrofluorescence of sediment humic substances and historical changes of lacustrine organic matter provenance in response to atmospheric nutrient enrichment. Environmental Science Techology,2002,36:3217- 
3223.

[20] Porcal P, Koprivnjak JF, MolotL A et al. Humic substances-part 7 : the biogeochemistry of dissolved organic carbon and its interactions with climate change. Environ Sci Pollut Res,2009,16:714-726.

[21] Fu PQ, Wu FC, Liu CQ et al. Spectroscopic characterization and molecular weight distribution of dissolved organic matter in sediment porewaters from Lake Erhai, Southwest China. Biogeochemistry,2006,81:179-189.

[22] Weishaar J, Aiken G, Bergamaschi B et al. Evaluation of specific ultraviolet absorbance as an indicator of the chemical composition and reactivity of dissolved organic carbon. Environmental Science \& Techology, 2003,37:4702-4708.

[23] 傅平清,刘丛强,尹祚莹等. 腐殖酸三维苂光光谱特性研究. 地球化学, 2004,33(3):301-308.

[24] 孙莉英, 倪晋仁, 孙卫玲. 不同粒径黄河沉积物中可提取腐殖质的含量分布及光谱特性. 环境科学, 2007,28(6): 1324-1331.

[25] 陈 兰,唐晓红,魏朝富. 土壤腐殖质结构的光谱学研究进展. 中国农学通报,2007,23(8):233-239.

[26] 刘亚子,高占启. 腐殖质提取与表征研究进展. 环境科技,2011,24(1):76-80.

[27] 张彩华. 光谱法在腐殖质研究中的应用进展. 光谱实验室,2011,28(2):693-696.

[28］姜忠峰, 张 生, 李畅游等. 乌梁素海表层沉积物重金属分布特征及生态风险评价. 环境工程学报,2012,6(6): 1810-1816.

[29] 郭旭晶, 席北斗,谢 森等. 乌梁素海沉积物孔隙水中溶解有机质的苂光及紫外光谱研究. 环境工程学报,2012,6 (2) $: 440-444$.

[30］甄小丽.乌梁素海富营养化评价及污染现状. 内蒙古科技与经济,2012,(2):32-34.

[31] 吕昌伟,崔 萌, 高际玫等. 硅在湖泊沉积物上的吸附特征及形态分布研究. 环境科学, 2012,33(1):135-141.

[32］史小红. 乌梁素海营养元素及其存在形态的数值模拟分析 [学位论文]. 呼和浩特: 内蒙古农业大学,2007.

[33] 高 敏.乌梁素海沉积物对磷吸附特性的粒度效应研究 [学位论文]. 呼和浩特: 内蒙古农业大学,2011.

[34] 陈伟民,黄祥飞,周万平. 湖泊生态系统观测方法. 北京: 中国环境科学出版社,2005:82-93.

[35］ NY/T 85-1988. 土壤有机质测定法. 1988.

[36 ］ LY/T 1238-1999. 森林土壤腐殖质组成的测定. 1999.

[37] 孙鸿烈,刘光崧. 土壤理化分析与剖面描述. 北京: 中国标准出版社, 1996:33.

[38］ NY/T 1121.2-2006. 土壤 pH 检测方法. 2006.

[39] 金相灿. 沉积物污染化学. 北京: 中国环境科学出版社, 1992:26-27,72-74.

[40] 赵胜男, 李畅游, 史小红等. 乌梁素海沉积物有机质特征及其与富营养化的关系. 第三届全国农业环境科学学术研 讨会论文集,2009,10:611-616.

[41] 孙惠民,何 江, 吕昌伟等.乌梁素海沉积物中有机质和全氮含量分布特征. 应用生态学报,2006,17(4):620-624.

[42］张晋京,窦 森.土壤胡敏素研究进展. 生态学报,2008,28(3):1229-1239.

[43] 窦 森, 李 凯, 崔俊涛等. 土壤腐殖质形成转化与结构特征研究进展. 土壤学报, 2008,45(6):1148-1158.

[44] 戴万宏, 黄 耀,武 丽. 中国地带性土壤有机质含量与酸碱度的关系. 土壤学报,2009,46(5):851-860.

[45] 张林海, 王瑞申. 闽江河口秋茄湿地土壤腐殖质组成及剖面分布特征. 云南地理环境研究, 2011,23(1):5-10.

[46] 秦伯强,许 海,董百丽. 富营养化湖泊治理的理论与实践. 北京:高等教育出版社,2011:118.

[47] Sheng WT, Yang CD, Fan SH. Variation of soil properties of Chinese fir plantation. Forest Research, 2003, 16 (4) :377-385.

[48］党亚爱,李世清, 王国栋. 黄土高原典型区域土壤腐殖酸组分剖面分布特征. 生态学报,2012,32(6): 1820-1829.

[49] 赵万苍, 何 江, 宋文杰等. 达里诺尔湖表层沉积物中腐殖质的分布特征. 农业环境科学学报, 2011, 30(2): 341-346.

[50］文启孝.土壤有机质的组成、形成和分解.土壤,1984,14(4):121-129.

[51] 蔡 颖, 钟 巍, 薛积涁等. 干旱区湖泊沉积物腐殖化度的古气候指示意义一一以新疆巴里坤湖为例. 湖泊科学, 2009,21 ( 1 ) :69-76.

[52] 窦 森, 王 帅. 不同微生物对形成不同腐殖质组分的差异性研究进展. 吉林农业大学学报, 2011, 33(2): 119-125.

[53] 毛海芳.乌梁素海、岱海有机碳的地球化学特征 [学位论文]. 呼和浩特: 内蒙古大学,2009.

[54] 关 松,窦 森. 土壤有机质分解与转化的驱动因素. 安徽农业科学,2006,34(10):2203-2206. 